\title{
DEVELOPMENT OF SCIENTIFIC TOURISM AT BAIKONUR COSMODROME KAZAKHSTAN
}

\author{
Asima G. KOSHIM* \\ Al-Farabi Kazakh National University, Al-Farabi Avenue 71, \\ 050040, Almaty, Kazakhstan, e-mail: asima.koshim@gmail.com
}

\section{Aigul M. SERGEYEVA}

K. Zhubanov Aktobe Regional State University, Department of Geography and Tourism, Moldagulova Ave 34, 03000o, Aktobe, Kazakhstan, e-mail: aiko-sm@mail.ru

\section{Kuat T. SAPAROV}

L. N. Gumilyev Eurasian National University, Department of Physical and Economical Geography, 2 Mirzoyanst, 010008, Astana, Kazakhstan, e-mail: k.sapar67@yandex.ru

\section{Jan A. WENDT}

Gdańsk University, Faculty of Oceanography and Geography, Institute of Geography, Bażyńskiego Str. 4, 80-309 Gdańsk, Poland, e-mail: jan.wendt@ug.edu.pl

\begin{abstract}
Citation: Koshim, A.G., Sergeyeva, A.M., Saparov, K.T., \& Wendt J.A. (2019). DEVELOPMENT OF SCIENTIFIC TOURISM AT BAIKONUR COSMODROME KAZAKHSTAN. GeoJournal of Tourism and Geosites, 24(1), 267-279. https://doi.org/10.30892/gtg.24121-358
\end{abstract}

\begin{abstract}
Many people see tourism as travelling, relaxing, getting new experiences and having a good time. However, considering it from different perspective, tourism can be developed and be related to other things. Current research is dedicated to one of the types of tourism - scientific tourism. After researching and defining the word "scientific tourism", it has been considered as a new type of tourism. The classification of scientific tourism depends on the mission of that tourism. The result has shown that there are two types of scientific tourism: expedition and individual. The modern classification of these two types of scientific tourism is considered as introductory or educational. The research has shown that Kazakhstan has enough resources to develop scientific tourism. As an example, Baikonur Cosmodrome has been considered for future scientific and space tourism.
\end{abstract}

Key words: tourism, types, scientific tourism, research, scientific expeditions, cosmodrom Baikonur, development, space tourism

\section{INTRODUCTION}

Tourism has been and remains as one of the leading and main profitable sector of global economy, despite, even the global economic crisis (2008). For rapid growth and

\footnotetext{
* Corresponding author
} 
development, it is recognized as economic phenomenon of the XX century (Żegleń \& Grzywacz, 2016), as it determined the levels of world relations between states and territories, influenced their economic and social development, legislative decision making, development systems the of world, continental and local tourist connections. In many countries, tourism plays significant role in the formation of gross domestic product, creation of additional workplaces and employment of the population (especially at small island states, where it is the main revenue source) (Stauvermann \& Kumar, 2016), intensification of the foreign trade balance (for example of our Republic of Kazakhstan and China). Tourism has huge impact on transport (Cirer-Costa, 2016), communications (Arikan, 2017, construction, production of consumer goods and others.

Tourism in the view of most people is associated with travel, leisure, new experiences, pleasure. It is natural for person to strive to discover and know uncharted lands, monuments of nature, history and culture, customs and traditions of different nations. But tourism can also be considered from the other side, it has many types and prospects for the development in certain conditions, in particular, economic development of the country. Therefore, classification of tourism serves as the basis for the development of target and regional programs using industry-specific economic standards applicable for given region, for diverse development of territories, protection of ecosystems, etc.

It also makes it possible to determine the place of the tourist industry among other sectors of regional economy, calculate profit that tourism can provide (Birzhakov, 2004; Gozner \& Avram, 2010; Ilieş \& Wendt, 2015; Ilieş et al., 2016). One of the types of tourism to which the research is devoted is scientific tourism. Scientific tourism and scientific heritage is relatively new concept, although it has long history (Jafari et al., 1992; Ilieş \& Josan, 2009). Novelty lies in the fact that especially today scientific tourism ceases to be exotic and becomes the subject of normal market circulation. As a concept, scientific tourism includes ecological, and ethno cultural, and underwater, and many other species, but the main feature is the active participation of tourist in the tour process (Ilyina, 1992). Scientific tourism includes cognitive system of scientific research in the regions and in general throughout the country. Cognitive part allows tourists to exchange various areas of research, in which new scientific ideas are born. Excursion-treatment services and resort-treatment activities that promote healing and recreational rest should be tightly linked to scientific communication. It must be said that scientific tourism is quite well developed in the USA, where it is called "learning travel", which means educational, cognitive or scientific tourism (West, 2008; Kosiewicz, 2014). Scientific tourism is also one of the most developing industries in the Saguenay-Lac-Saint-Jean region of the Canadian province of Quebec (www.intacadem.ru), where it is planned to expand the scope of scientific tourism and include active participation in such activities as speleology and archeology, agriculture, criminology, literature or medicine to educational routes.

In Europe also, it is the type of tourism that has become very popular among many people involved in science (Brouder, 2014; O'Gorman et al., 2014; McClinchey, 2015; Hung et al., 2016), politics (Mihalič et al., 2016) and culture (Truchet et al., 2016). About six hundred international scientific meetings and congresses are held in Germany every year. Germany is on $4^{\text {th }}$ place by this type of tourism. The largest cities - centers of scientific tourism are Berlin, Hamburg, Munich, Hanover, and Frankfurt am Main. Likewise in other European countries (Austria, France, Italy, the Czech Republic, etc.) international fairs, conferences and congresses in various fields of science are held annually. The Republic of Kazakhstan has all the prerequisites for the development of all types of tourism, including scientific, because tourism has been recognized as one of the developing economic sectors and entered the list of priority non-primary sectors of the economy of Kazakhstan as a cluster №1 (Saduov, 2014; Gozner, 2010; Ilieş et al., 2017, 2018). 


\section{MATERIALS AND METHODS \\ Object of research}

The object of research is the world's first and largest cosmodrome Baikonur, located in Kyzylorda region, of $350 \mathrm{~km}$ north from the railway station Toretam. The name of the cosmodrome coincides with the same name of small town, which is located next to the village station Toretam. It was suggested by the Soviet secret service in order to confuse the "potential enemy" in search of the real location of the cosmodrome.The territory of Baikonur cosmodrome is $6,717 \mathrm{~km}^{2}$ (https://www.advantour.com/rus) The Baikonur cosmodrome and the city of the same name together form the Baikonur complex, leased by Russia from Kazakhstan for the period until 2050.

\section{Research methods}

Research used descriptive method for comprehensive disclosure of the topic, as well as a set of complementary methods: information retrieval, analysis and systematization of scientific publications and media materials on the object and subject of research, comparative method, statistical and cartographic method (using satellite images from Google Earth Pro: www.maps-world.ru/sputnic.htm).

The analysis of publications on the subject of research allows to define the concept and types of scientific tourism. As it was noted that most researchers mainly consider general special types and nature of tourism, causes and prerequisites for their occurrence (Birzhanov, 2002; Babkin, 2008; Serikova \& Orazbayeva, 2010), some analyze various aspects of tourism in general (Kvartalnov, 2002; Karpova \& Lavrova, 2009). Only some authors, single out scientific tourism as a separate independent type (Kholodilina, 2011; Pavlov: http://www.intacadem.ru), at the same time, linking it with ecological one (Panov, 1998; Kholodilina, 2011,) and cultural type (Pavlov: http://www.intacadem.ru).

In order to identify the relation between scientific tourism and environmental tourism, we have analysed foreign literature, where some authors consider ecotourism "in an amicable way of doing business" (Bădulescu \& Bâc, 2009), others believe that the development of ecotourism requires motivation factors such as self-development, interpersonal relations, evaluation of nature and so on (Carvache-Franco et al., 2019), Whereas the rest associates it with geotourism (Ovreiu et al., 2019), that in principal is a scientific tourism. Aspects of the formation of regional tourist clusters of Kazakhstan were also considered, to one of which the considered study area is attributed (Artemyev \& Abdreyeva, 2015). System analysis was used as the main research tools, quantitative methods of collecting and processing information were used qualitatively. Calculations were based on the data of the Committee on Statistics of the MNE RK. When defining scientific tourism, the characteristic of the term was taken from Glossary Commander: Service thematic explanatory dictionaries (http: // www.glossary.ru).

\section{RESULTS DISCUSSIONS}

During the years of independence and with the transition of Kazakhstan to market relations, tourism has taken its firm place, both in the economy and in science. For the development of young republic, its entry into the world arena for establishing international relations and attracting investments was important and necessary.

Kazakhstan had to present itself as a new independent subject of international relations, because for many Kazakhstan was terra incognito, uncharted land. It was necessary to present its capabilities, its people, its potential, therefore representatives of the intelligentsia and scholars were always part of our state delegations. They looked at various models of economic and political development of other countries. It was necessary on the spot to understand the advantages and disadvantages of various models of modernization, to explore the possibilities of transferring foreign experience 
to Kazakhstani soil. This was the most positive path for the development of political, economic and other systems in Kazakhstan. The geography of international relations of our republic covers almost all continents. Among our partners are leading countries in Asia, Europe, America and Australia. Relations of Kazakhstan with the USA, China, Japan, France, Canada, Turkey, Iran, India, Pakistan, Egypt, Saudi Arabia, Hungary and other Eastern European states, with the Baltic States, Scandinavia, Ukraine and Transcaucasia are successfully developing.

With the establishment of international relations, quite a lot of serious and diverse scientific research has appeared in various sectors of the economy, including types of international tourism and its organization, allowing to form the necessary basis for comprehensive study of conditions and factors, increasing the efficiency of resource use in the region for the development of particular type of tourism.

All these conditions, in turn, required qualified specialists, for which departments of tourism were opened in many universities of the republic. Currently, tourism is distinguished by quantitative changes. According to UNESCO, the annual number of international tourists is 625 million people (Kholodilina, 2011). First of all, it concerns scientific, environmental-expeditionary, sports-educational and cultural tourism, since science and culture affect the main motivations of people movement.

Figure 1 presents the data of the MNE RK on the number of visitors by type of tourism in Kazakhstan for 2011-2017. The data presented show the growth rate of all types of tourism. These rates are not identical in different years, but, nevertheless, gradual growth is obvious. This is the reason for the intensive development of tourism, both as a science and as a branch of economic activity (Figure 1). Scientific tourism is one of the least studied and underdeveloped types of tourism, so it is still in the initial stage of development. There is an opinion that considers scientific tourism as a regular trip, with the aim of participating in various conferences, congresses and symposia (Senin, 2003; Kholodilina, 2012). We agree with this opinion, because international scientific conferences always set goals for establishing scientific links between scientists, contacts, and for solving these or other common tasks that concern the world community.

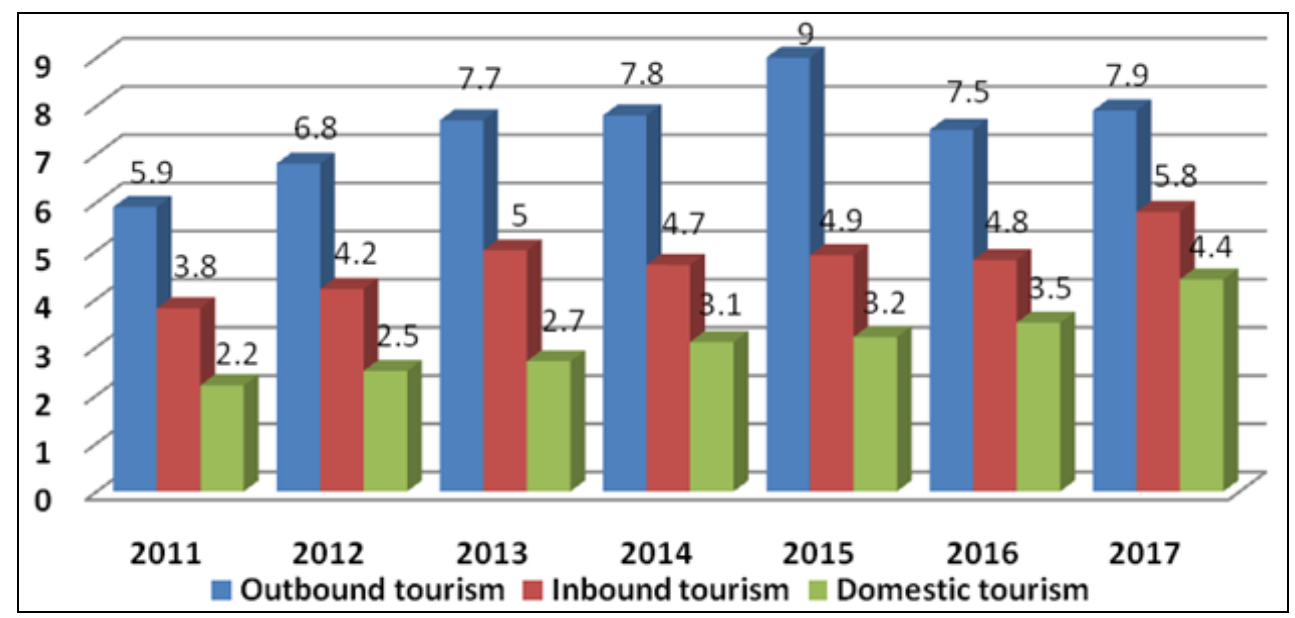

Figure 1. Number of visitors served by type of tourism (thousand people) (Source: http://stat.gov.kz.)

Under the term "scientific tourism" every researcher has his own opinion. Some understand the type of tourism, the purpose of which is professional research of interest 
to science, familiarization with the history of scientific research, the uniqueness of natural resources (www.intacadem.ru). Others believe that scientific tourism is the implementation of research (scientific) activity in a specific area, which is not the tourist's place of residence during the period from 24 hours to 6 months in a row without gaining material gain (Kholodilina, 2011: 169). Still others believe that scientific tourism is a trip and collection of information about the culture and life of the population in a given period, which are the basis for the development of scientific tourism (Kvartalnov, 2002).

The Charter of Cultural Tourism, adopted by UNESCO (Kholodilina, 2012:169) and the World Tourism Organization (WTO), the Manila Declaration on World Tourism gives the following definition: "Scientific and cultural tourism is aimed inter alia - personal knowledge of scientific achievements and discovery of historical sites and monuments". (Kvartalnov, 2002:4; Dorofeyev, 2010). Based on the analysis of existing definitions of scientific tourism, the following concept is adhered: scientific tourism is the implementation of scientific activity with the personal participation of researcher on specific territory without any material benefit. The main distinguishing feature of scientific tourism from any other types of tourism is the active participation of the researcher in the tour program. According to experts of the Russian Geographical Society (RGO), (http://www.knt.org.ru), there are two main types of scientific tourism:

- expeditionary, as part of field organization of scientific organization;

- independent scientific tourism at your own risk.

Expeditionary scientific tourism, in turn, can be divided into:

- archaeological;

- restoration, (study and restoration of ancient monuments and buildings);

- ethnographic (study of national cultures, customs and traditions of peoples);

- study of rare animals in reserves;

- geological, etc.

Independent scientific tourism here is understood as follows: when a group or one traveler, at their own risk go to poorly studied regions and even countries, study abandoned or wild places, shoot video films. With this opinion we disagree a little. We believe that this is a common educational tourism. At present, some researchers divide scientific tourism into three main types (Kholodilina, 2011; https://www.svastour.ru):

- introductory, in order to familiarize with the history and uniqueness of natural resources, historical and cultural heritage, the education system, which is a feature of tourism potential and is successfully used by many countries as an element of attracting tourist flows, in particular, as the basis of educational tourism. For example, the worldfamous universities of Oxford, Cambridge, Harvard have long become tourist attractions and independent objects of the tourist show. The possibility of obtaining prestigious education attracts students from different regions, which strengthens established and sustainable segment of the consumer market.

- supporting participation: tourists take part in scientific works or expeditions as auxiliary personnel (participation in restoration works, work in reserves for the conservation of rare animals, field research);

- independent, i.e. independently study and explore nature, its flora, fauna which is of interest to science, thanks to the help and explanations of the scientific staff.

When conducting scientific and practical conferences and seminars, educational institutions are often used for tourism purposes, where tourist organizations can provide various services to scientific societies (holding meetings, events providing scientific information, visiting scientific objects, etc.).

Analyzing proposed classification of scientific tourism, the following can be said: 
- the first type - introductory scientific tourism, is no different from ordinary educational tourism;

- the second type, auxiliary scientific tourism is the same as expeditionary tourism, because the tourist, taking part as auxiliary staff, is a member of the expedition itself. It includes foreign research expeditions, study of remote and new areas, when scientists from many countries jointly investigate world problems (global warming of the climate, formation of ozone layer, melting glaciers, study of Antarctica (where scientists from our country took part), human survival in extreme conditions (Everest), etc.; This may also include carrying out scientific field research;

- the third type of scientific tourism is quite well developed, when quite a few scientific researchers independently or in a group of 2-3 people conduct regular trips with a scientific purpose, for example, participation at international scientific conferences, seminars, commissions, etc. According to available estimates, participants of such international events make up $6-7 \%$ of the total number of foreign temporary visitors, and they account for about $10 \%$ of foreign exchange earnings from tourism (Serikova \& Orazbayeva, 2010). Thus, it follows from this that only those trips can be attributed to scientific tourism, where the main goal of the tourist is not acquaintance with the object, but active participation in the scientific work of expedition or group. In the age of scientific and technological revolution, scientific complexes are important resource of scientific tourism. Specialized planetariums, nuclear power plants, space centers, as well as nature reserves, aquanariums, museums and exhibitions, etc. should be considered among the most popular scientific objects. Excursions to scientific objects can be organized both for specialists in a specific field of knowledge and for mass tourists.

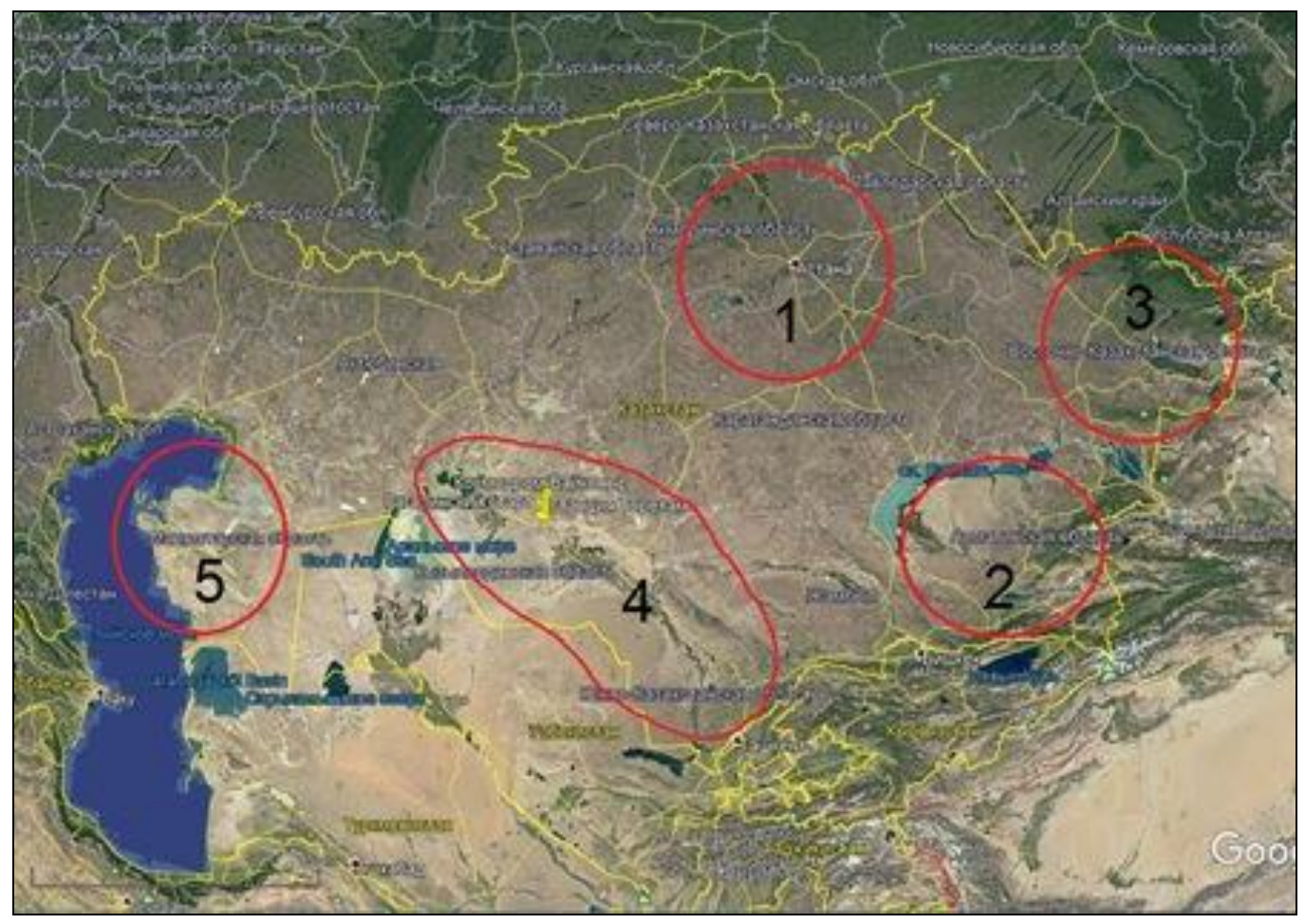

Figure 2. Planned tourist clusters of Kazakhstan, between them Baikonur - in the $4^{\text {th }}$ cluster of the Republic (Source: https//kapital.kz/) 
Kazakhstan has sufficient resources for scientific tourism, namely:

- developed system of scientific research in the widest areas, which are concentrated by the Ministry of Education and Science (the National Academy of Sciences of Kazakhstan was reorganized in 1996 and became part of the Ministry of Education and Science, and since 2003 it is a public association);

- variety of natural landscapes and biosphere reserves and national parks;

- interesting architectural monuments;

- interesting historical, memorial complexes of different eras;

- centers of various national traditional crafts.

Not all of these resources are fully mastered by the tourist business. Their development requires investment, and thoughtful plan to create competitive tourism products. Currently, there are few methods for designing scientific tourism products, in which a number of its specific features have to be taken into account. There is also the problem of personnel capable of organizing and conducting scientific tours of studied objects. One of such interesting objects not only for tourists, but also for science is Baikonur - the largest and most developed cosmodrome of the planet, whose territory is included in five planned tourist clusters of the republic (Figure 2). Five tourist cluster in Kazakhstan (1. Astana; 2. Almaty; 3. East Kazakhstan with Altai; 4. South Kazakhstan region and revival of the Great Silk Road; 5. West Kazakhstan region, the Caspian Gate).

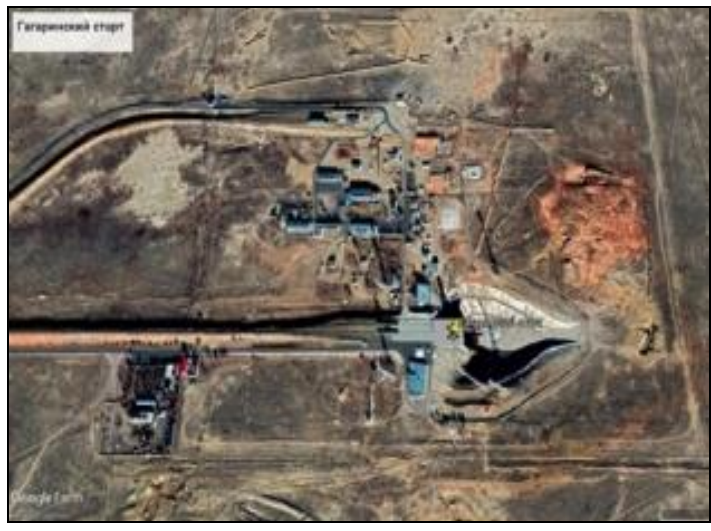

Figure 3. Location of the complex "Gagarin's start"

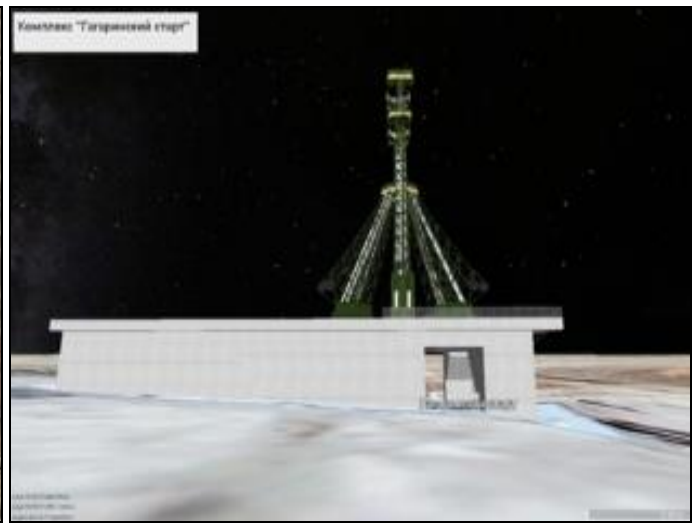

Figure 4.Complex "Gagarin's start"

(Source: Satellite world map: Google Earth Pro: www.maps-world.ru)

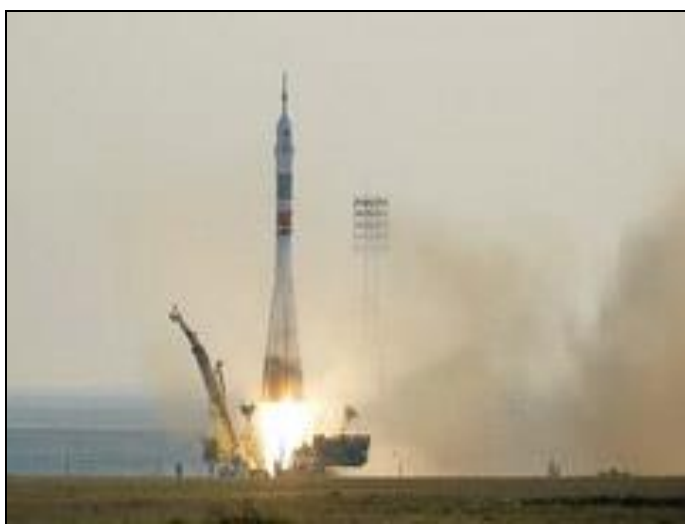

Figure 5. Rocket launch

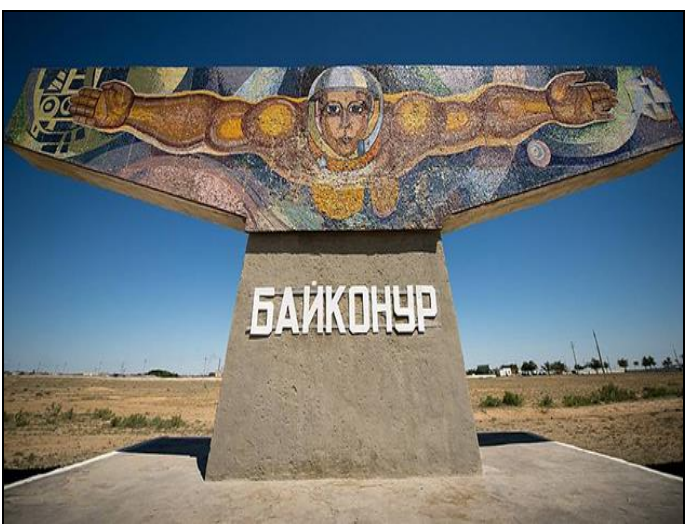

Figure 6. Statue at the entrance to Baikonur 
It annually attracts a huge number of visitors and offers educational and scientific information to tourists who do not even have knowledge in this area (Figure 2-4, satellite images are taken from Satellite world map: Google Earth Pro: www.maps-world.ru).

As it is known to everyone, the first artificial satellite of the Earth was launched from the Baikonur cosmodrome, and then the first manned flight into space took place (Figure 3, 4) In the following years, the "Vostok", "Voskhod" and "Soyuz" manned space rockets, orbital stations of "Salyut" and "Mir" series, the "Energiya" - "Buran" reusable systems, interplanetary spacecraft and artificial Earth satellites were launched from Baikonur (Figure 5). To the south of the cosmodrome $(350 \mathrm{~km})$ there is the city of Baikonur of the same name (Figure 6), where almost all the sights are connected precisely with cosmonautics. The tourist potential of the city is huge. The most popular among tourists are the Cosmodrome History Museum, the International Space School, the Gagarin's Arbor, the Cosmonauts Alley and the Cosmonaut Hotel, where the cosmonauts stop before space flight. Only in this city you can see the launch of a real rocket. Almost every street in Baikonur has monument in honor of scientists, astronauts, writers and poets. For the development of tourism there are all the prerequisites in the city, because the city (officially considered closed city) becomes available, but tourism there develops and works according to certain rules (http://strana.ru; https://habr.com/ru/post). Tourists in this city, as well as in reserves, move only when accompanied by employees of tourist companies. To visit this city, it is necessary to send application to the travel agency no less than 60 days before the date of intended visit. Alsp permission is needed from Roscosmos and get permission to visit the cosmodrome and its facilities, as well as approve permission for professional film and photo works (https://24.kz/ru/news/social/item).

But, nevertheless, scientific tourism in this city has its beginning. The city of Baikonur annually hosts the International Scientific Competitions for Space Research for Schoolchildren called "Discovering the World of Science" (https://www.buro247.kz). Competitions are aimed at stimulating research abilities of schoolchildren to applied research in the field of science of Earth and Space, space technologies, modeling and astrophysics. In addition to the performance of schoolchildren with research projects, exhibitions of materials, models and devices of the participants are organized. Leading Russian scientists in the field of Earth and Space Science are present at these competitions as guests. In April 2018, on the eve of Cosmonautics Day, the XIV space research competition took place. Organization of such event in the city of Baikonur has become traditional; it opens up the scientific world of cosmonautics to the younger generation. In addition, on August 26, 2016 the Association of Physics Students and Young Scientists of Russia (APS Russia http://www.imp.uran.ru) and the International Space School of Baikonur organized visit of physics students and young scientists to the city and the Baikonur Cosmodrome with a conference seminar entitled "Physics to space. Modern and advanced space research and technology". The conference program included thematic excursions and visits to museums, historical, memorable places and scientific and technical centers of the city of Baikonur; visiting memorial sites, museums and scientific and technical space centers of the Baikonur cosmodrome, and also roll-out can be seen- installation of launch vehicle at the launch site of the spaceship, which is made 3 days before launch and see the launch of the vehicle itself (http://sktur.ru). After the events, participants can be offered excursions around Baikonur (Table 1), visit memorable sights, including Baikonur Cosmodrome Museum, which houses unique collections, including the Moon Globe, personal belongings of the first cosmonaut Yu.A. Gagarin, the first satellite of the Earth, "Union", "Belka" and "Strelka"capsules. The International Space School, can be visited, where there is a meeting with the leadership, teachers and students of unique space school and where rocket model can be independently launched. 
The city also has a huge number of monuments set up in honor of famous scientists and researchers who devoted their lives to science and space: Yu.A. Gagarin, S.P. Korolev and others. Academician S.P. Korolev is the first founder of the city and the cosmodrome, so Baikonur has square and avenue, named after him, where is a monument devoted to him. As can be seen, the tourist potential of Baikonur is huge. Every year, cosmodrome attracts groups of travelers from Holland, Spain, Switzerland, Poland and other countries.

Table 1.Suggested tours at Baikonur

\begin{tabular}{|c|c|c|}
\hline № & $\begin{array}{l}\text { Excursions on the } \\
\text { cosmodrome Baikonur }\end{array}$ & Brief description \\
\hline 1 & $\begin{array}{l}\text { Sightseeing tour at the city of } \\
\text { Baikonur (travel information } \\
\text { about the history of the city, } \\
\text { stops at memorials and } \\
\text { monuments) }\end{array}$ & $\begin{array}{l}\text { The Baikonur complex is international space port providing } \\
\text { reliable implementation of Russian and international space } \\
\text { programs. Baikonur retains its leading position in the global } \\
\text { space infrastructure for over 50 years. The history of the } \\
\text { international space port is full of interesting and diverse pages } \\
\text { related to the names of great people of the 2oth century, with } \\
\text { interesting engineering projects, which were ahead of their } \\
\text { time in many ways.The rapid growth of the city occurred in the } \\
1980 \text { s in connection with the development of the space } \\
\text { program "Energiya-Buran", which caused large flow of } \\
\text { specialists from all over the USSR. }\end{array}$ \\
\hline 2 & Baikonur Cosmodrome & $\begin{array}{l}\text { The Baikonur Cosmodrome is unique scientific and technical } \\
\text { complex. Over the past } 50 \text { years, it has become the largest } \\
\text { cosmodrome in the world. Its area is } 7000 \text { square km; It is } \\
75 \mathrm{~km} \text { long from north to south and } 90 \mathrm{~km} \text { from west to east. } \\
\text { The cosmodrome includes } 9 \text { launch complexes ( } 15 \text { launch } \\
\text { sites); } 11 \text { test sites, } 3 \text { filling stations for space ships and } 2 \\
\text { airfields. At present, Baikonur is open for worldwide } \\
\text { cooperation in the field of space exploration, for orbital } \\
\text { stations of new generation, for manned cosmonautics, which } \\
\text { is the only and largest space center in the world. }\end{array}$ \\
\hline 3 & $\begin{array}{l}\text { Excursion at the } \\
\text { International } \\
\text { Space School }\end{array}$ & $\begin{array}{l}\text { The International Space School (ISS) was established in } 1990 \\
\text { by the decision of the Board of the Ministry of Education. } \\
\text { When the Baikonur complex was leased to the Russian } \\
\text { Federation in 1995, the name and status of the school were } \\
\text { retained by the decision of the Government of the Russian } \\
\text { Federation and the Republic of Kazakhstan. }\end{array}$ \\
\hline 4 & $\begin{array}{l}\text { Visit to the monument } \\
\text { of the newcomer of space }\end{array}$ & $\begin{array}{l}\text { The sculptural composition shows the history of the creation } \\
\text { of the "Space Harbor" }\end{array}$ \\
\hline 5 & $\begin{array}{l}\text { Museum complex of } \\
\text { the cosmodrome } \\
\text { (museum, } \\
\text { orbital ship "Buran", } \\
\text { historical houses of S.P. } \\
\text { Korolev and Yu.A.Gagarin) }\end{array}$ & $\begin{array}{l}\text { The uniqueness of the museum lies in the fact that there are } \\
\text { unique exhibits that are of great interest to visitors. Among } \\
\text { them - the ejection seat with a dummy, which was used to test } \\
\text { the parachute system during flight and space tests of the } \\
\text { "Vostok" type spacecraft on March 25, 1961, options for } \\
\text { returning sealed cockpits used in conducting biomedical } \\
\text { experiments on animals. }\end{array}$ \\
\hline 6 & $\begin{array}{l}\text { Excursion to the Museum } \\
\text { of the history } \\
\text { of BaikonurCosmodrome }\end{array}$ & $\begin{array}{l}\text { The Baikonur Cosmodrome History Museum was opened in } \\
\text { 1967. At present, the exposition includes more than } 15,000 \\
\text { storage units, four halls are functioning: hall of military and } \\
\text { labor glory, hall of history of the development of rocket and } \\
\text { space technology, outer space hall, ethnographic hall and } \\
\text { exhibition gallery. The museum holds large video library with } \\
\text { films about space, the Baikonur cosmodrome, as well as } \\
\text { educational and popular science films on astronomy. }\end{array}$ \\
\hline
\end{tabular}


There are many prerequisites for the development of scientific tourism in the region, although it is believed that scientific tourism makes up a small share in the total tourist flow, but, however, its role is quite large. In particular, it can significantly replenish information about the study area and objects (which was previously considered closed), and can be useful not only for the development of science, but also for the further development of tourism in this region on a sustainable basis. At the same time, scientific tourism can contribute to the expansion of scientific and educational ties between various countries, laying the foundation for important and relevant international projects carried out on grants of charitable foundations. With such meetings and exchanges, new scientific ideas are born, and scientists receive strong impetus for creative development for the state of mind (Pirozhnik, 1996; Senin, 2003).

As it is known, one component is necessary for the development of tourism, including scientific, - uniqueness of the territory. Uniqueness of the territory is the originality, exclusiveness of the site or the object located on it and rarity in relation to other objects and territories. Exclusiveness of the site of territory or object lies in its location, natural and climatic factors, its historical development process, peculiarities of the biocenosis, etc. There are many remarkable places in the world marked by the history of human civilization as unique. One of these places on Earth is the Baikonur Cosmodrome, rightly called the first space harbor of the planet. Baikonur is unique in its complex, because it is the first and largest space center in the world. Tourists even have great opportunity to attend the launch of manned or unmanned missiles from the cosmodrome according to the launch schedule.

In terms of nature and resources, Baikonur is located in a semi-desert zone between $45^{\circ} 7^{\prime} \mathrm{N}$. and $63^{\circ} 18^{\prime} \mathrm{E}$. The relief of the territory is a flat accumulative plain, in the southern part of which, the Syr-Darya River flows from east to west. The entire territory is characterized by the presence of drainless depressions, occupied mainly by salt marshes or takyrs. On the territory there are small arrays of fixed hilly sands, sand mounds have a height of $2-10 \mathrm{~m}$. The climate is continental: the winter is mild, the average temperature is - (minus) $10^{\circ}$, summer is hot, the temperature rises to $+40^{\circ}$ degrees. Prevailing wind direction is east and west. There is very little rainfall, the average long-term precipitation is $98 \mathrm{~mm}$. However, the weather practically does not affect the launch of rockets: the launch can be transferred only in the case of storm wind with a speed of more than $50 \mathrm{~m} / \mathrm{s}$, which is exceptional phenomenon.

In the southern part of Baikonur, the Syr-Darya River flows, in its lower course it has no inflows. The water in it is sandy-earthy in color and contains a lot of silt particles, therefore it requires long sludge and filtration. The river flows among the loamy-sandy plain, covered with sandy mounds, towering 10-20 meters above it. The valley of the river has no clear boundary. In high-water years, during high water, as well as in winter, when river jams in various places, they overflow their banks, forming significant spills. The width of the river until the mid-70s was 200 meters. Since then, the width of river has significantly decreased and in the area of the city of Baikonur does not exceed 100 meters. The prevailing depth of the river is 3 meters, the maximum depth is 8 meters (Figure 3). The soil and vegetation cover of the territory is represented mainly by light chestnut saline soils.

The middle and southern part of the territory is covered with sparse vegetation, consisting of a wide variety of wormwood, salt worts and camel thorn. There is no continuous vegetation cover anywhere, the plants are located at considerable distance from each other. In some places there is absolutely bare soil. Tugai thickets and bushes are widespread along the Syr-Darya lowland. The sandy areas are represented by fixed hilly sands with extremely thin soil cover. Sand vegetation is easily destroyed. 
The city of Baikonur and a number of residential and industrial sites of the cosmodrome are artificially well landscaped, although the grass cover is mostly insignificant, there are large number of trees).

\section{CONCLUSIONS}

The XXI century must become the century of the development of scientific tourism. The phenomenon of the new century will be scientific expeditions and scientific stations that are included to the orbit of tourism (https://bnews.kz/ru/news). Therefore, in order to develop scientific tourism in the region under study, the following is proposed in the future:

$>$ It is necessary to promote domestic science, which should serve society. For this, it is necessary to restore the National Academy of Sciences of the Republic of Kazakhstan, as the center of science and scientific research;

$>$ To create interesting and attractive scientific basis for tourist facilities in order to interest local authorities in organizing tourist routes, expeditions and research;

$>$ To provide training of qualified personnel for tourist firms, organizing scientific tours;

To popularize economic importance of scientific tourism, as well as any kind of tourism that will become source of replenishment of the regional budget. Well-established scientific tourism will contribute to the growth of science, culture and the general economy of both the region and the country as a whole.

According to UNESCO experts, the share of scientific tourism by 2020 will be $25 \%$ of the total world tourism, or about two trillion US dollars per year (Kholodilina, 2012), which will actually complete the process of turning tourism into the leading complex of world scientific and cultural development, since science and culture affects the basic motivations of people movement. Scientific tourism will allow to attract trained enthusiasts to conduct various fundamental and applied research in various fields of science and technology, significantly expanding the boundaries of these studies in our Republic in all areas. And in this case, annual scientific competitions and conferences in Baikonur will be the basis for the development of space tourism, behind which the future stands (http://www.unikaz.asia/ru).

\section{REFERENCES}

Artemyev, A.M., \& Abdreyeva, Sh.T. (2015). Tourism of Kazakhstan: Formation of regional tourist clusters / Tourism and recreation: basic and applied research. Proceedings of the $\mathrm{X}$ International Scientific Practical Conference. Moscow: The dialogue of cultures, pp.231-237.

Arikan, E. (2017). Engagement with online customers in emerging economies: The power of online brand communities and social networking sites. Promotional Strategies and New Service Opportunities in Emerging Economies. pp. 184-209.

Babkin, A.V. (2008). Special types of tourism M.: Soviet sport, pp.154-155.

Bădulescu A., \& Bâc D (2009). Profile of ecotourists in Apuseni mountains natural park. GeoJournal of Tourism and Geosites. Year II, no. 1, vol. 3, pag. 7-16.

Birzhakov, M.B. (2008). Introduction to tourism. Edition 9, revised and enlarged - SPb. Gerda Publishing House. -576 p.

Brouder, P. (2014). Ю Evolutionary economic geography and tourism studies: extant studies and future research directions. Tourism Geographies. 16(4), pp.540-545.

Carvache-Franco, M., Segarra-Oña, M., \& Carrascosa-López, C. (2019). Motivations analysis in ecotourism through an empirical application: segmentation, characteristics and motivations of the consumer. GeoJournal of Tourism and Geosites, Year XII, vol. 24, no. 1, p.60-73.

Cirer-Costa, J.C. (2016). Cinema and the automobile: Driving factors of new tourism models in the early years of the Golden Age. Tourism Management Perspectives, 19, pp.24-31.

Dorofeyev, A.A. (2010). Ecotourism as a factor of nature conservation and biodiversity conservation, in: Bulletin of TverState University. - Issue 20, pp.115-123. 
Gozner, M., \& Avram, M. (2010). The situation of the natural reservation from the Territorial System Albac - Arieseni. Analele Universităţii din Oradea, Seria Geografie, Tom XX, Editura Universităţii din Oradea; http://journals.indexcopernicus.com/karta.php?action=masterlist\&id=3951.

Gozner, M. (2010). Tourism in the Territorial System Albac - Arieseni sistemul teritorial Albac and its impact on the environment. Analele Universităţii din Oradea, Fascicula Construcţii şi Instalaţii Hidroedilitare, vol. XIII - 2, Editura Universităţii din Oradea

Ilieş, A., \& Wendt, J.A. (2015). Geografia turystyczna. Podstawy teorii i zagadnienia aplikacyjne [Tourist geography. Basic theory and application issues]. Wydawnictwo AWFiS: Gdańsk.

Ilieş, D.C., \& Josan, N. (2009). Geosites - geomorphosites and relief. GeoJournal of Tourism and Geosites, Year $1(3), 78-85$.

Ilieș, A., Wendt, J.A., Ilieş, D.C., Herman, G.V., Ilieş, M., \& Deac, A.L. (2016). The patrimony of wooden churches, built between 1531 and 2015, in the Land of Maramureș, Romania. Journal of Maps, Volume 12, 2016, pp 597-602 - Issue sup1 (http://dx.doi.org/10.1080/17445647.2016.1243075).

Ilies, D.C., Buhas, R., Ilies, M., Ilies, A., Gaceu, O., Pop, A.C., Marcu, F., Buhas, S.D., Gozner, M., \& Baias, S. (2018). Sport Activities and Leisure in Nature 2000 Protected Area - Red Valley, Romania. Journal of Environmental Protection and Ecology, 19, No 1, 367-372.

Ilies A., Hurley Peter D., Ilies D.C., \& Baias S, (2017). Tourist animation -a chance adding value to traditional heritage: case studys in the Land of Maramures (Romania). Revista de etnografie si folclor, New Series 1-2.

Hung, W.L., Lee, Y.J., \& Huang, P.H. (2016). Creative experiences, memorability and revisit intention in creative tourism. Current Issues in Tourism, 19(8), pp.763-770.

Karpova, G.A., \& Lavrova, T.A. (2008). Theoretical foundations of the development of inventory of tourist resources. News. SPb. № 4 (56).

Kosiewicz, J. (2014). Scientific tourism, Aspects, Religious and Ethics Values. Sport and Ethics: Philosophical Studies, vol. LXII, special issue, 83-93.

Kvartalnov, V.A. (2002). Modern features of tourism as a scientific knowledge and research. Theory and practice of physical culture. - №11, pp. 3-9.

McClinchey, K. (2015). Travel books, place experience and the 'Je ne sais quoi' of Paris. Tourism Geographies, 17(5), pp.701-718.

Mihalič, T., Šegota, T., Knežević Cvelbar, L., \& Kuščer, K. (2016). The influence of the political environment and destination governance on sustainable tourism development: a study of Bled, Slovenia Journal of Sustainable Tourism, 24(11), pp.1489-1505.

O'Gorman, K.D., MacLaren, A.C., \& Bryce, D. (2014). A call for renewal in tourism ethnographic research: the researcher as both the subject and object of knowledge. Current Issues in Tourism, 17 (1), pp.46-59

Ovreiu A. B., Bărsoianu I. A., Comănescu L., \& Nedelea A. (2019). Capitalizing of the geotourism potential and its impact on relief. Case study: Cozia massif, Romania. GeoJournal of Tourism and Geosites, Year XII, vol. 24, no. 1, 2019, p.212-236.

Panov, I.N. (1998). Ecotourism and its role in the sustainable development of territories, in: Bulletin of Moscow University, Series 5. Geography. - № 6, pp.25-34.

Pirozhnik, I.I. (1996). International tourism in the world economy: Manual. Mn.: Belarus State University, 49 p.

Saduov, Zh.A. (2014). Analysis of the current state of tourism in Kazakhstan, in: Bulletin of Karagandy State University, [Electronic resource]. Access mode: https://articlekz.com/article/8507. Appeal date: 22.01.2019

Senin, V.S. (2003). Organization of international tourism: Textbook, Moscow: Finance and Statistics. 400 p.

Serikova, G.T., \& Orazbayeva, K.N. (2010). The essence of tourism and features of its research in the socioeconomic aspect, Bulletin of KazEU, Series of Economics. - №4, pp. 5-10.

Stauvermann, P.J., \& Kumar, R.R. (2016). Economics of tourism and growth for small island countries. Tourism Management, 55, pp.272-275.

Truchet, S., Piguet, V., Aubert, F., \& Callois, J.M. (2016). Spatial influence of attractions on tourism development. Tourism Geographies. 18(5), pp.539-560

Kholodilina, Yu. Ye. (2011). Theoretical aspects of the development of scientific tourism in the region, in: Bulletin of Orenburg State University №13 (132), pp.500-505.

Kholodilina, Yu. Ye. (2012). Resource potential of the region as a basis for the development of scientific tourism, in: Bulletin of Orenburg State University №8 (144), pp. 169-173. Gdańskiego: Gdańsk.

West, P. (2008). Tourism as Science and Science as Tourism. Environment, Society, Self, and Other in Papua New Guinea. Current Anthropology, vol. 49, 597-611.

Żegleń, P., \& Grzywacz, R. (2016). Tourism as an economic phenomena of XXI century. Scientific Review of Physical Culture, 6 (1), 26-31.

*** Ashim, Ye.Baikonur - Homeland of space tourism. [Electronic resource]: Access Mode: http://www.unikaz.asia/ru/content/baykonur-rodina-kosmicheskogo-turizma. Appeal date: 01/21/2019 
*** Baikonur: 55 years after the first flight into space. [Electronic resource]: Access Mode: https://www. buro247.kz/lifestyle/travel/baykonur-gorod-mechta-spustya-55-let-posle-pervogo-poleta-v-kosmos. html. Appeal date: 21.01.2019.

*** Baikonur can develop space tourism. [Electronic resource]: Access Mode: https://bnews.kz/ru/news/ kosmicheskie_attraktsioni_dlya_turistov_poyavyatsya_bliz_baikonura. Appeal date: 20.01.2019.

*** Capital. Economy Section. [Electronic resource]: Access Mode https://kapital.kz/economic/26077/v-rkopredeleny-pyat-klasterov-turizma.html. Appeal date: 16.03.2019.

*** Development of space tourism is included in the joint plan of Kazakhstan and Russia for 2019. [Electronic resource]: Access Mode: http://strana.ru/journal/news/25334221. Appeal date: 21.01.2019. Experience of space tourism. [Electronic resource]: Access Mode: https://habr.com/ru/post/419573/. Appeal date: 21.01.2019.

*** Excursion to the BaikonurCosmodrome. [Electronic resource]: Access Mode: http://sktur.ru/bezrubriki/ekskursiya-na-kosmodrom-baykonur/ Appeal date: 23.01.2019.

***** Glossary Commander: Service of thematic explanatory dictionaries [Electronic resource]. - Access mode: http:// www.glossary.ru/cgi_bin. Appeal date: 11.01.2019

*** Golubev, S.V. Scientific tourism is more a part of the lifestyle, or a kind of active recreation not only for intellectuals. [Electronic resource]: Access Mode: https://www.knt.org.ru/Nauchnuy\%20Turizm.htm. Appeal date: 15.01.2019

*** M.N. Mikheev Institute of Metal Physics of the Ural Branch of the Russian Academy of Sciences (IMP UB RAS): Visit to the Baikonur Cosmodrome-2016 and the conference "Physics-to-space" [Electronic resource]: Access Mode: http://www.imp.uran.ru/?q=ru/content/vizit-na-kosmodrom-baykonur-

Appeal date: 16.03.2019

*** Official website of the Committee on Statistics of the Republic of Kazakhstan (tourism and culture section) [Electronic resource]: Access Mode: http://stat.gov.kz. Appeal date: 25.01.2019.

**** Pavlov, V.P. Scientific tourism: accumulated experience and development prospects [Electronic resource]. Access mode: http://www.intacadem.ru/ tatji/nauchnyy_turizm_nakoplennyy_opyt_i_perspektivy razvitiya.html. Appeal date: 10.01.2019.

*** Satellite world map: Google Earth Pro: www.maps-world.ru/sputnic.htmScientific tourism. [Electronic resource]: Access Mode: https://www.svastour.ru/articles/puteshestviya/vidy-turov/nauchnyyturizm.html. Appeal date: 19.01.2019.

*** The Baikonur Cosmodrome. Launch pad to space. [Electronic resource]: Access mode: https://www. advantour.com/rus/kazakhstan/baikonur/cosmodrome.htm. Appeal date: 01/20/2019

*** Tourism is a phenomenon of XX century. [Electronic resource]. Access mode: http://artkavun. kherson.ua /turizm fenomen_xx_veka.htm- Appeal date 19.01.2019

*** Usmanova, A. Space tourism: course at Baikonur. [Electronic resource]: Access Mode: https://24.kz/ru/news/social/item/276433-ploshchad-razvlekatelno-turistskoj-zony-bajkonuruvelichili-do-100-ga. Appeal date: 22.01.2019.

Submitted:

21.01.2018
Revised:

27.03.2019
Accepted and published online 29.03.2019 